\title{
Tuning the composition of plasma-activated water by a surface-wave microwave discharge and a kHz plasma jet
}

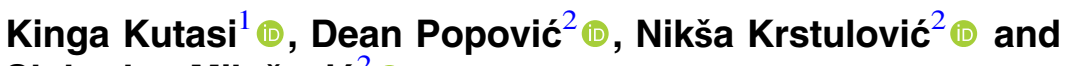 \\ Slobodan Milošević ${ }^{2}$ (i) \\ ${ }^{1}$ Wigner Research Centre for Physics, Institute for Solid State Physics and Optics, Hungarian Academy of \\ Sciences, POB 49, H-1525 Budapest, Hungary \\ ${ }^{2}$ Institute of Physics, Bijenička cesta 46, 10000 Zagreb, Croatia \\ E-mail: kutasi.kinga@wigner.mta.hu
}

Received 8 March 2019, revised 25 June 2019

Accepted for publication 16 August 2019

Published 6 September 2019

\begin{abstract}
An atmospheric pressure surface-wave microwave discharge and a $\mathrm{kHz}$ plasma jet are used to activate purified water. It is shown, that by varying the treatment distance and the initial $\mathrm{Ar} / \mathrm{N}_{2} / \mathrm{O}_{2}$ mixture composition of the surface-wave microwave discharge the concentration ratio of $\mathrm{NO}_{3}^{-}$and $\mathrm{H}_{2} \mathrm{O}_{2}$ radicals created in the plasma activated water (PAW) can be varied over three orders of magnitude, which can be preserved during months of storage at room temperature. At the same time, with the $5 \mathrm{~min}$ treatment of the $32 \mathrm{ml}$ water the absolute radical concentrations are varied in the range of $0.5-85 \mathrm{mg} \mathrm{l}^{-1}$ for $\mathrm{H}_{2} \mathrm{O}_{2}, 20-180 \mathrm{mg} \mathrm{l}^{-1}$ for $\mathrm{NO}_{3}^{-}$and $0.5-14 \mathrm{mg} \mathrm{l}^{-1}$ for $\mathrm{NO}_{2}^{-}$. In the case of the $\mathrm{N}_{2} \mathrm{kHz}$ plasma jet this concentration ratio can be tuned within one order of magnitude by varying the treatment distance. By treating different volumes very similar concentration ratios are obtained, which evolve differently during storage, as the ageing dynamics is determined by the absolute concentration of radicals. In general, the radical most affected by ageing is $\mathrm{NO}_{2}^{-}$, whose recombination is found to be determined by the $\mathrm{H}_{2} \mathrm{O}_{2}$ radical. In order to control the $\mathrm{H}_{2} \mathrm{O}_{2}$ concentration and thus the $\mathrm{NO}_{2}^{-}$radicals recombination, the application of a Fenton type reaction is suggested, which is implied by inserting a copper surface into PAW during or after plasma treatment.
\end{abstract}

Keywords: plasma activated liquids, surface-wave microwave discharge, plasma jet

\section{Introduction}

In the last decade plasma-activated water (PAW), or more generally plasma-activated liquid (PAL) has received a lot of attention from the plasma medicine and plasma agriculture community due to its potential to induce oxidative stress to cells. By PAL it is meant the liquid which contains reactive species, mostly reactive oxygen and nitrogen species (RONS), generated by the interaction of active or afterglow plasma with the liquid. PAW has been found to have antimicrobial and antibacterial effect [1-9], which is thought to occur due to the synergetic effect between the RONS and/or $\mathrm{pH}$ of the solution [3, 5]. Plasma activated buffered solution and cell culture media has also been studied for therapeutical aims [10-12], and it has been shown its potentials for cancer therapy [11]. In the field of agriculture with PAW the improvement of seeds germination and plant growth have been targeted [13-15].

The lifetime of PAL has been found to be very different, varying from days to months, depending on the plasma source used. Several works define the PAL lifetime as its activity retention time [16-19], while others follow the lifetime of different RONS in the PAW [5, 16, 18-20]. The main longlived RONS produced in PAL have been identified to be the $\mathrm{H}_{2} \mathrm{O}_{2}, \mathrm{NO}_{3}^{-}$and $\mathrm{NO}_{2}^{-}$[21]. In a $60 \mathrm{ml} \mathrm{ns}$ pulsed DBD air plasma treated water the $\mathrm{NO}_{2}^{-}$molecules could be detected up to 25 min, while the concentration of $\mathrm{H}_{2} \mathrm{O}_{2}$ decreased by a factor of 2 [18]. On the other hand in a $10 \mathrm{ml}$ DBD activated water Traylor et al [5] have found that the lifetimes of $\mathrm{H}_{2} \mathrm{O}_{2}$ and nitrite are up to $4 \mathrm{~d}$, while the nitrate concentration 
Table 1. Typical plasma activated liquids found in the literature. Concentration of long lived radicals in PALs created with different plasma sources in deionized water (DIW), phosphate buffer saline solution (PBS), phosphate buffer (PB) and 5 mmol $1^{-1} \mathrm{~N}$-acetyl-cysteine in PBS (NAC), respectively.

\begin{tabular}{|c|c|c|c|c|c|c|c|c|}
\hline Liquid & Plasma system & $V[\mathrm{ml}]$ & $t[\mathrm{~min}]$ & $\mathrm{pH}$ & {$\left[\mathrm{H}_{2} \mathrm{O}_{2}\right]\left[\mathrm{mg} \mathrm{l}^{-1}\right]$} & {$\left[\mathrm{NO}_{2}^{-}\right]\left[\mathrm{mg} \mathrm{l}^{-1}\right]$} & {$\left[\mathrm{NO}_{3}^{-}\right]\left[\mathrm{mg} \mathrm{l}^{-1}\right]$} & References \\
\hline DIW & Air gliding arc & 20 & 5 & 3.0 & 0.34 & 73 & 8 & [3] \\
\hline DIW & Air DBD & 10 & 30 & 2.7 & 3 & 1.0 & 64 & [6] \\
\hline DIW & Air DBD & 5 & 30 & 2.7 & 18 & 1.5 & 113 & [6] \\
\hline DIW & Air DC microjet & 20 & 20 & 3.2 & 80 & 21 & 37 & [32] \\
\hline DIW & He rf jet & 0.5 & 5 & 4.2 & 50 & - & - & [4] \\
\hline DIW & Air DBD & 10 & 20 & 2.7 & 3.4 & 55 & 74 & [5] \\
\hline DIW & Air corona & 10 & 60 & 2.8 & 50 & - & - & [16] \\
\hline PBS & Air corona & 10 & 60 & 6.5 & 100 & - & - & [16] \\
\hline Water & Negative corona & - & 180 & - & 3 & 120 & - & {$[30]$} \\
\hline PBS & Air DBD & 0.15 & 5 & 6.5 & 2.7 & 161 & 186 & {$[33]$} \\
\hline NAC & Air DBD & 1 & 3 & 2.58 & 30 & - & 239 & {$[34]$} \\
\hline Saline & Ar rf jet & 3.35 & 33 & 4.1 & 20 & 0.5 & 6 & {$[35]$} \\
\hline Water & Electrospray spark & 2.5 & 5 & 3.3 & 24 & 9 & 62 & [25] \\
\hline PB & Electrospray spark & 2.5 & 5 & 6.2 & 14 & 28 & 56 & {$[25]$} \\
\hline PB & Pulsed DC & 900 & 30 & 3.3 & 7 & 4 & 8 & [21] \\
\hline DIW & Air ns DBD & 60 & 5 & 2.7 & 8.5 & 7 & 93 & [18] \\
\hline DIW & Air ns DBD & 60 & 10 & 2.3 & 10 & 4.6 & 217 & [18] \\
\hline PBS & $\mathrm{He}-1 \% \mathrm{~N}_{2}$ DBD jet & 2 & 10 & 7.2 & - & 27 & 28 & {$[36]$} \\
\hline DIW & Air rf microjet & 35 & 30 & 2.1 & 10 & 0 & 155 & {$[37]$} \\
\hline DIW & He rf microjet & 35 & 30 & 2.3 & 15 & 0 & 93 & [37] \\
\hline DIW & Ar rf microjet & 35 & 30 & 2.6 & 24 & 0 & 93 & {$[37]$} \\
\hline DIW & He DC jet & 0.3 & 2 & - & 27 & - & - & [38] \\
\hline DIW & $\mathrm{He}$ BDB jet & 3 & 30 & - & 3.43 & 1.69 & 0.79 & [39] \\
\hline
\end{tabular}

increases slightly during the $7 \mathrm{~d}$ of observation. Julák et al [16] have observed the total disappearance of $\mathrm{H}_{2} \mathrm{O}_{2}$ (initial concentration of about $5 \mathrm{mg} \mathrm{l}^{-1}$ ) from the $10 \mathrm{ml}$ corona discharge treated water in 1 month. Shen et al [19] have followed the evolution of species concentration- $0.81 \mathrm{mg} \mathrm{l}^{-1}$ of $\mathrm{H}_{2} \mathrm{O}_{2}, 1.2 \mathrm{mg} \mathrm{l}^{-1}$ of $\mathrm{NO}_{2}^{-}$and $14.6 \mathrm{mg} \mathrm{l}^{-1}$ of $\mathrm{NO}_{3}^{-}$-in $10 \mathrm{ml}$ microjet activated water stored at different temperatures: $25^{\circ} \mathrm{C}, 4{ }^{\circ} \mathrm{C},-20{ }^{\circ} \mathrm{C}$ and $-80{ }^{\circ} \mathrm{C}$. At $25^{\circ} \mathrm{C}$ after $30 \mathrm{~d}$ the initial concentration of $\mathrm{H}_{2} \mathrm{O}_{2}$ decreased by a factor of 5 , of $\mathrm{NO}_{2}^{-}$by a factor of 8 , while that of $\mathrm{NO}_{3}^{-}$by a factor of 3 . By lowering the storage temperature the recombination of $\mathrm{H}_{2} \mathrm{O}_{2}$ and $\mathrm{NO}_{2}^{-}$decreased, and the freezing of $\mathrm{NO}_{2}^{-}$could be realized at $-80^{\circ} \mathrm{C}$. Julák et al [20] have stored the $30 \mathrm{~min}$ air corona treated $1.5 \mathrm{ml}$ water at $4{ }^{\circ} \mathrm{C}$ over 1 year and have measured the decrease of the initial $126 \mathrm{mg} \mathrm{l}^{-1} \mathrm{H}_{2} \mathrm{O}_{2}$ to $41 \mathrm{mg} \mathrm{l}^{-1}$.

Lukes et al [21] have shown that the concentration of species and their lifetime depend on the $\mathrm{pH}$ of treated water. At acidic conditions ( $\mathrm{pH} 3.3$ ) lower concentrations of $\mathrm{NO}_{2}^{-}$ and $\mathrm{H}_{2} \mathrm{O}_{2}$, and higher concentrations of $\mathrm{NO}_{3}^{-}$were detected as compared to conditions of $\mathrm{pH} 6.9$ and 10.1. At the same time during the after-treatment period under acidic conditions the $\mathrm{NO}_{2}^{-}$and $\mathrm{H}_{2} \mathrm{O}_{2}$ concentrations decreased, and that of $\mathrm{NO}_{3}^{-}$ increased, while at higher $\mathrm{pHs}$ the concentrations did not change.

The typical concentrations reported in the literature for the main RONS are summarized in table 1. Several studies have been triggered by the plasma medicine applications, therefore a small quantity of liquids have been treated, volumes of typical cell culture plates. Higher treated volumes range between 10 to $60 \mathrm{ml}$, and depending on the plasma source used very different species concentrations are obtained. However, these works report typically one or two PAL conditions, giving no further suggestions for PAL composition tuning. In order to be able to identify the role of different species and to clarify the synergy effects in the interaction of PAL with biological systems, PAL with different compositions would be welcomed, in what concerns the density ratios of different RONS. For tuning the PAW composition an attempt has been done by Ito et al [22] by using a He DBD jet with different shielding gases, thus obtaining ratios of $\left[\mathrm{NO}_{2}^{-}\right] /\left[\mathrm{H}_{2} \mathrm{O}_{2}\right]$ ranging between 0 and 0.18 . However, here no information is given about the density of $\mathrm{NO}_{3}^{-}$molecules, which can be also formed during storage from the reaction of $\mathrm{NO}_{2}^{-}$with $\mathrm{H}_{2} \mathrm{O}_{2}$ [21]. By transforming an air DBD into a DBD jet by flowing He through the array electrode, a slight tuning of the species concentration in the treated water has been achieved when varying the gas flow rate in the $0-8 \mathrm{slm}$ range [23]. Namely, in an $8 \mathrm{ml} 3 \mathrm{~min}$ treated DIW the $\mathrm{H}_{2} \mathrm{O}_{2}$ concentration increased from 0.3 to $5.8 \mathrm{mg} \mathrm{l}^{-1}$, the concentration of $\mathrm{NO}_{2}^{-}$decreased from 5.5 to $1.4 \mathrm{mg} \mathrm{l}^{-1}$ and that of $\mathrm{NO}_{3}^{-}$varied between 19.8 and $13.6 \mathrm{mg} \mathrm{l}^{-1}$, while the $\mathrm{pH}$ ranged between 2.4 and 2.7.

In the present work the tuning possibility of PAW composition through the treatment of purified water with a surface-wave microwave discharge and a $\mathrm{kHz}$ plasma jet is studied. Furthermore, the ageing of PAWs with different 
compositions are also followed, and solutions for controlling the PAW ageing are searched for.

\section{Plasma systems and production of plasma activated water}

Active species have been generated in purified water by putting the water surface in contact with the plasma plume of a $\mathrm{kHz}$ plasma jet and a surface-wave microwave discharge, respectively. The water samples are analyzed immediately after the treatment, as well as several times during the three months of storage. The samples are kept in closed containers (clearglass container from Macherey-Nagel $\mathrm{GmbH}$ ) filled up to few mm below cap, at room temperature $\left(20^{\circ} \mathrm{C}-22{ }^{\circ} \mathrm{C}\right)$ and predominantly in dark.

The concentration of $\mathrm{NO}_{2}^{-}, \mathrm{NO}_{3}^{-}$and $\mathrm{H}_{2} \mathrm{O}_{2}$, and the $\mathrm{pH}$ of samples are measured with QUANTOFIX ${ }^{\circledR}$ test strips (Nitrate/ Nitrite 500: $10-500 \mathrm{mg} \mathrm{l}^{-1} \mathrm{NO}_{3}^{-}, 0.5-80 \mathrm{mg} \mathrm{l}^{-1} \mathrm{NO}_{2}^{-}$; Nitrate/ Nitrite 100: 5-100 mg l ${ }^{-1} \mathrm{NO}_{3}^{-}, 0.5-50 \mathrm{mg} \mathrm{l}^{-1} \mathrm{NO}_{2}^{-}$; Peroxide 25: $0.5-25 \mathrm{mg} \mathrm{l}^{-1}$; Peroxide 100: 0.5-25 $\mathrm{mg} \mathrm{l}^{-1}$ ) and evaluated with the QUANTOFIX ${ }^{\circledR}$ Relax unit (by Macherey-Nagel, $\mathrm{GmbH}$ ). The test strips calibrated by the producer to certified standard solutions allow fast analyzing without the waste of the sample, thus making possible to follow the ageing of PAWs even with high temporal resolution. On the other hand, the QUANTOFIX Relax reader allows quantitative analysis of strips with high accuracy ${ }^{3}$. The measuring error has been determined to be less than $10 \%$ (typically $6 \%-8 \%$ ).

\subsection{Plasma jet}

The atmospheric pressure plasma jet consists of a quartz tube with the outer and inner diameters of 1.5 and $1 \mathrm{~mm}$, respectively, and a copper wire of 100 microns diameter, which is inserted in the capillary and serves as the powered electrode [24]. The powered electrode is connected to a high voltage power supply, which provides a sinusoidal waveform of $28 \mathrm{kHz}$ with $12 \mathrm{kV}$ maximum voltage. The discharge is ignited in $\mathrm{N}_{2}$ gas (99.996\% purity), which is supplied into the capillary typically with a flow rate of $500 \mathrm{sccm}$. The purified water-commercial purified water of Pharmaceutical degree (Pharmacopoeia Europaea, Ph. Eur. 9) with pH 6.5 from the KEMIG d.o.o. Croatian company-in Berzelius beaker is brought in contact with the plasma jet by placing the water surface from the capillary orifice at distances in the $1-10 \mathrm{~mm}$ range. The treated volumes have been 25,125 and $200 \mathrm{ml}$.

\subsection{Surface-wave microwave discharge}

The surface-wave microwave discharge is generated with the help of a surfatron launcher (Sairem, Surfatron 80) in a quartz tube of outer diameter $6 \mathrm{~mm}$ and inner diameter $4 \mathrm{~mm}$, using

\footnotetext{
3 We have also performed test measurements on chemically prepared solution characterized as $0 \mathrm{mg} \mathrm{l}^{-1} \mathrm{H}_{2} \mathrm{O}_{2}, 2 \mathrm{mg} \mathrm{l}^{-1} \mathrm{NO}_{2}^{-}$and $50 \mathrm{mg} \mathrm{l}^{-1} \mathrm{NO}_{3}^{-}$. The strip measurements have been performed after freezing and defrosting the solution, and obtained concentrations of $0 \mathrm{mg}^{-1} \mathrm{H}_{2} \mathrm{O}_{2}, 2.1 \mathrm{mg} \mathrm{l}^{-1} \mathrm{NO}_{2}^{-}$ and $55 \mathrm{mg} \mathrm{l}^{-1} \mathrm{NO}_{3}^{-}$.
}

as a main gas Ar at gas flow rates of 1500-2000 sccm. During experiments $\mathrm{Ar}-\mathrm{N}_{2} / \mathrm{O}_{2}$ binary and ternary mixtures are also used with the $\mathrm{O}_{2}$ and $\mathrm{N}_{2}$ gas flow rates ranging between 10 and $100 \mathrm{sccm}$. The input power is varied between 25 and $30 \mathrm{~W}$, while the reflected power can be up to a maximum of $1 \mathrm{~W}$. The quartz tube is fixed inside the surfatron in such a way, that downstream from the closing plate of the surfatron the edge of the quartz tube is at $14.5 \mathrm{~mm}$ distance. This insures that at the powers and gas flow rates used the plasma plume outside the tube is long enough to allow different contact points with the water surface. A Berzelius beaker of $35 \mathrm{ml}$ filled with $32 \mathrm{ml}$ of purified water is positioned below the plasma plume with the water surface being at $5.5,8.5$ or $10.5 \mathrm{~mm}$ distances from the edge of the quartz tube. The purified water is produced with the ELGA Purelab Option-R 7 purifier and is characterized by Total Organic Carbon (TOC) $<20 \mathrm{ppb}$, Bacteria $<1 \mathrm{CFU} / \mathrm{ml}$, Inorganic-Typical $>15 \mathrm{M} \Omega \mathrm{cm}$. In order to avoid the overheating of the quartz tube during treatments, compressed air is applied along the quartz tube with a gas flow rate of $8 \mathrm{slm}$, which on the other hand has also shielding effect. The surface-wave microwave discharge being an electrodeless discharge can have a significant advantage by avoiding the contamination of liquid with nanoparticles originating from the sputtering of the electrodes, as observed in some cases [25]. Due to their advantages surface wave-microwave discharges have also been studied for biological applications [26].

The surface-wave microwave discharges have also the advantage of the high flexibility in tuning the plasma composition [27]. The surface-wave microwave discharge consists of a plasma column, characterized with a decreasing electron density profile along the column, with the critical electron density occurring at the end of it [28]. At atmospheric pressure the plasma column can extend over the discharge tube (with a slight change in the electron density profile at the exit of the quartz tube due to the change of the guiding dielectric [26]), as shown in figure 1. Due to this property, by changing the distance between the discharge tube and the water surface, different electron density can be achieved at the interaction surface. In our study, as a reference condition it is chosen the $2000 \mathrm{sccm}$ Ar and $25 \mathrm{~W}$ discharge, with the discharge tube-water surface distance of $5.5 \mathrm{~mm}$. In order to vary in the plasma plume the density of $\mathrm{NO}$ and $\mathrm{NO}_{2}$ molecules (which contribute to the formation of nitrite and nitrate ions in the PAW), $\mathrm{N}_{2}$ and $\mathrm{O}_{2}$ gases can be added to Ar. The sustainment of the discharge and the length of the plasma column depend on the power absorption of electrons from the electromagnetic field, which is determined by the electron collision frequencies [29]. When molecular gasses are added to argon, due to the change of the power absorption, larger input power is necessary to sustain a stable discharge, while the length of the plasma column also decreases, as illustrated in figure 1. Therefore, using different $\mathrm{Ar} / \mathrm{N}_{2} / \mathrm{O}_{2}$ mixtures and treatment distances, both the electron and the $\mathrm{NO}$ and $\mathrm{NO}_{2}$ densities can be tuned at the plasma-water interaction surface. 


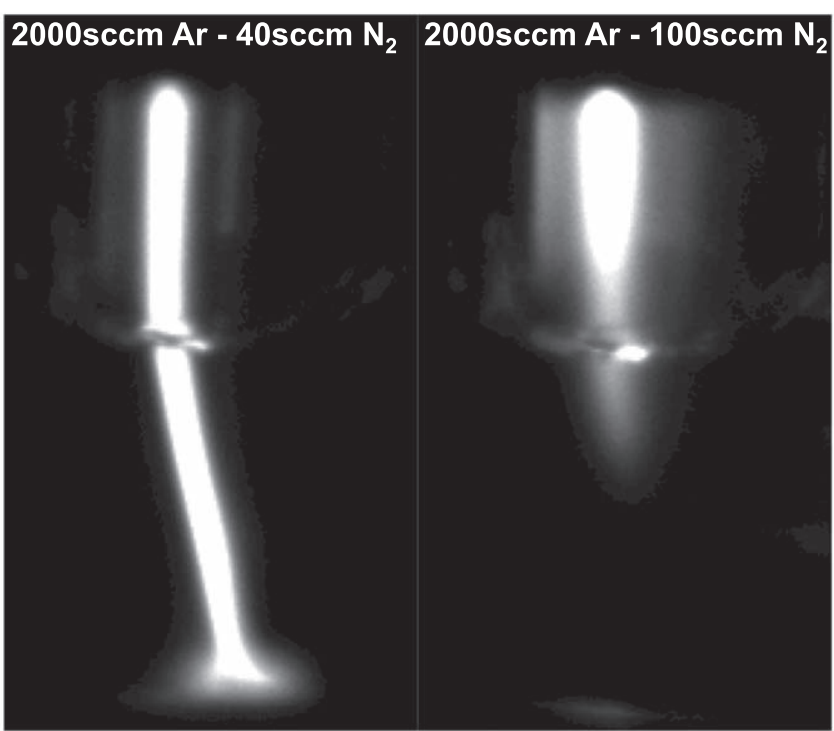

Figure 1. Image of the plasma plume in the case of $2000 \mathrm{sccm} \mathrm{Ar}-$ $40 \mathrm{sccm} \mathrm{N} \mathrm{N}_{2} 27 \mathrm{~W}$ and $2000 \mathrm{sccm} \mathrm{Ar}-100 \mathrm{sccm} \mathrm{N} \mathrm{N}_{2} 30 \mathrm{~W}$ surfacewave microwave discharges.

\section{Results and discussion}

\subsection{The PAW produced with the surface-wave microwave discharge}

Table 2 shows the different treatment conditions applied and the characteristics of the generated plasma activated water. First of all, different Ar discharge conditions have been tested by changing the gas flow rate and the treatment distance. As the plasma plume is characterized by a decreasing electron density profile, by changing the treatment distance the electron density is also changed at the plume-water surface interaction point. The electrons interacting with water molecules at the gas-water interface can create $\mathrm{OH}$ radicals, which afterwards in the $\mathrm{OH}+\mathrm{OH} \longrightarrow \mathrm{H}_{2} \mathrm{O}_{2}$ recombination reaction form $\mathrm{H}_{2} \mathrm{O}_{2}$. This is well illustrated by the obtained results, namely, at the lower treatment distance, where higher electron density occurs at the water surface, higher $\mathrm{H}_{2} \mathrm{O}_{2}$ concentration is obtained (condition Ar_1 versus Ar_2). By decreasing the gas flow rate (the Ar_3 condition), the plasma plume becomes slightly shorter, while more air is able to diffuse into the plume, which favoures the formation of nitrate and nitrite radicals.

Figure 2 shows the spectra of the plume close to the water surface in the case of two different quartz tube-water surface distances. The intensity of the $\mathrm{OH}$ band (the $\mathrm{OH}(\mathrm{A}-$ $\mathrm{X})$ transition $(0,0)$ bandhead at $308.5 \mathrm{~nm}$ ) is considerably lower comparing to the $\mathrm{N}_{2}$ bands and Ar lines intensity, suggesting, that the $\mathrm{OH}$ radicals are created at the gas-liquid interphase, instead of the plasma plume. The spectra show, that the emission of the Ar states excited by electrons (in the $602-760 \mathrm{~nm}$ spectral range) are lower at the higher treatment distance, indicating a lower electron density. Additionally, we can also observe the emission of the $\mathrm{NO} \gamma$ and $\mathrm{NO} \beta$ bands (200-300 nm range) — which is a good indication for the presence of NO molecules-with higher intensity at the higher treatment distance. Meanwhile at the lower treatment distance, there is a marked signal of the $\mathrm{NO}_{2}$ green-yellow continuum, showing the presence of $\mathrm{NO}_{2}$ molecules. The dissolved $\mathrm{NO}$ and $\mathrm{NO}_{2}$ molecules contribute to the creation of nitrate and nitrite radicals in PAW through the following reactions:

$$
\begin{gathered}
\mathrm{NO}_{2(\mathrm{aq})}+\mathrm{NO}_{2(\mathrm{aq})}+\mathrm{H}_{2} \mathrm{O}_{\mathrm{l}} \longrightarrow \mathrm{NO}_{2}^{-}+\mathrm{NO}_{3}^{-}+2 \mathrm{H}^{+} \\
\mathrm{NO}_{(\mathrm{aq})}+\mathrm{NO}_{2(\mathrm{aq})}+\mathrm{H}_{2} \mathrm{O}_{1} \longrightarrow 2 \mathrm{NO}_{2}^{-}+2 \mathrm{H}^{+} \\
\mathrm{NO}_{(\mathrm{aq})}+\mathrm{OH}_{(\mathrm{aq})} \longrightarrow \mathrm{NO}_{2}^{-}+\mathrm{H}^{+} \\
\mathrm{NO}_{2(\mathrm{aq})}+\mathrm{OH}_{(\mathrm{aq})} \longrightarrow \mathrm{NO}_{3}^{-}+\mathrm{H}^{+}
\end{gathered}
$$

Additionally, the formation of $\mathrm{NO}_{3}^{-}$is also promoted through the $\mathrm{NO}_{2}^{-}+\mathrm{H}_{2} \mathrm{O}_{2}+\mathrm{H}^{+} \longrightarrow \mathrm{NO}_{3}^{-}+\mathrm{H}_{2} \mathrm{O}+\mathrm{H}^{+}$reaction, which results in relatively lower $\mathrm{NO}_{2}^{-}$concentration comparing to $\mathrm{NO}_{3}^{-}$.

By adding $\mathrm{N}_{2}$ to $\mathrm{Ar}$ (conditions $\mathrm{Ar}_{-} \mathrm{N}_{2}$ in table 2) the length of the plasma plume decreases, while the plasma becomes stable only at a higher $27 \mathrm{~W}$ power. This effect is well reflected by the lower $\mathrm{H}_{2} \mathrm{O}_{2}$ concentrations obtained with the Ar- $\mathrm{N}_{2}$ discharges comparing to Ar discharges (see Ar_1 versus $\mathrm{ArN}_{2} 1$ condition). Figure 3 shows the spectra close to the water surface when adding $40 \mathrm{sccm}, 60 \mathrm{sccm}$ and $100 \mathrm{sccm} \mathrm{N}_{2}$, respectively, to $\mathrm{Ar}$ in the case of $5.5 \mathrm{~mm}$ treatment distance. Comparing to the spectra of the Ar discharge (figure 2) the intensity of Ar lines gradually decreases with the $\mathrm{N}_{2}$ addition, which also indicates the lowering of the electron density. With the addition of $100 \mathrm{sccm}$ of $\mathrm{N}_{2}$ the emission intensity decreases significantly, which indicates, that the plasma plume becomes so short, that the water surface interacts with the plasma afterglow, as also illustrated by the plasma plume images in figure 1. Along the afterglow the electron density drops fast, while the density of $\mathrm{NO}$ and $\mathrm{NO}_{2}$ radicals also decrease. This results, as expected, in a lower $\mathrm{H}_{2} \mathrm{O}_{2}$ and nitrite/nitrate concentrations.

The NO $\gamma$ emission is also well observed in the afterglow region due to the fact that here the excited $\mathrm{NO}(\mathrm{A})$ molecules are created mostly through the three body recombination of $\mathrm{N}$ and $\mathrm{O}$ atoms. The afterglow conditions are also approached when increasing the treatment distance in the case of $40 \mathrm{sccm}$ and $60 \mathrm{sccm} \mathrm{N}_{2}$ mixture discharges, resulting in lower species concentrations in the PAW: $\mathrm{ArN}_{2} 1$ versus $\mathrm{ArN}_{2} 3$ conditions, and $\mathrm{ArN}_{2} \_5$ versus $\mathrm{ArN}_{2}$ 6, respectively. $\mathrm{ArN}_{2} 6$ and $\mathrm{ArN}_{2} 7$ conditions show, that similar effect can be obtained by decreasing the gas flow rate instead of changing the treatment distance. It is also found, that the doubling of the treatment time $\left(\mathrm{ArN}_{2}\right.$ 3. versus $\mathrm{ArN}_{2}$ 4. condition) practically doubles the active species concentrations in PAW.

When adding $\mathrm{O}_{2}$ to the Ar- $\mathrm{N}_{2}$ mixture, the discharge can be sustained at a lower power of $25 \mathrm{~W}$, similar to the case of pure Ar. Due to the lower input power and the different power absorption along the plasma column, the electron density along the plasma plume is lower than in the case of the $27 \mathrm{~W}$ input power $\mathrm{Ar}-\mathrm{N}_{2}$ mixture, which is well reflected by the lower $\mathrm{H}_{2} \mathrm{O}_{2}$ concentration obtained in the PAW: $\mathrm{ArN}_{2} \mathrm{O}_{2}$ versus $\mathrm{ArN}_{2} 1$ in table 2. On the other hand, when $\mathrm{O}_{2}$ is added to the pure Ar, such in the case of $20 \mathrm{sccm} \mathrm{O}_{2}$ to $2000 \mathrm{sccm} \operatorname{Ar}\left(\mathrm{ArO}_{2}{ }_{1}\right)$, the discharge's structure is very 
Table 2. The treatment conditions: gas flow rates, input power and quartz tube-water surface distance, and the surface-wave microwave discharge produced PAW's characteristics at different ageing moments. The PAWs could be reproduced with a maximum error of 5\%.

\begin{tabular}{|c|c|c|c|c|c|c|}
\hline I.D. & Conditions & $\begin{array}{c}t \\
{[\mathrm{~min}]}\end{array}$ & $\begin{array}{l}{\left[\mathrm{H}_{2} \mathrm{O}_{2}\right]} \\
{\left[\mathrm{mg} \mathrm{l}^{-1}\right]}\end{array}$ & $\begin{array}{l}{\left[\mathrm{NO}_{2}^{-}\right]} \\
{\left[\mathrm{mg} \mathrm{l}^{-1}\right]}\end{array}$ & $\begin{array}{l}{\left[\mathrm{NO}_{3}^{-}\right]} \\
{\left[\mathrm{mg} \mathrm{l}^{-1}\right]}\end{array}$ & $\overline{[\mathrm{pH}]}$ \\
\hline Ar_1. & $\begin{array}{l}2000 \mathrm{sccm} \mathrm{Ar} \\
25 \mathrm{~W}, 5.5 \mathrm{~mm}\end{array}$ & $\begin{array}{c}0 \\
95 \\
83567\end{array}$ & $\begin{array}{l}84 \\
63 \\
50\end{array}$ & $\begin{array}{l}6.8 \\
0.5 \\
0.5\end{array}$ & $\begin{array}{l}92 \\
49 \\
40\end{array}$ & $\begin{array}{l}5.7 \\
4.6 \\
6.6\end{array}$ \\
\hline Ar_2. & $\begin{array}{l}2000 \mathrm{sccm} \mathrm{Ar} \\
25 \mathrm{~W}, 10.5 \mathrm{~mm}\end{array}$ & $\begin{array}{c}0 \\
90\end{array}$ & $\begin{array}{l}60 \\
28\end{array}$ & $\begin{array}{l}16 \\
0.5\end{array}$ & $\begin{array}{c}178 \\
55\end{array}$ & $\begin{array}{l}5.8 \\
4.4\end{array}$ \\
\hline Ar_3. & $\begin{array}{l}1500 \mathrm{sccm} \mathrm{Ar} \\
25 \mathrm{~W}, 5.5 \mathrm{~mm}\end{array}$ & $\begin{array}{c}0 \\
93 \\
83554\end{array}$ & $\begin{array}{l}46 \\
25 \\
21\end{array}$ & $\begin{array}{l}12 \\
1.6 \\
0.5\end{array}$ & $\begin{array}{c}123 \\
61 \\
55\end{array}$ & $\begin{array}{l}5.4 \\
5.1 \\
6.2\end{array}$ \\
\hline $\mathrm{ArN}_{2} 1$. & $\begin{array}{l}2000 \mathrm{sccm} \text { Ar-40 sccm N } \\
27 \mathrm{~W}, 5.5 \mathrm{~mm}\end{array}$ & $\begin{array}{c}0 \\
82 \\
83535\end{array}$ & $\begin{array}{l}40 \\
36 \\
23\end{array}$ & $\begin{array}{l}12 \\
1.3 \\
0.5\end{array}$ & $\begin{array}{c}136 \\
63 \\
56\end{array}$ & $\begin{array}{l}5.3 \\
4.3 \\
6.3\end{array}$ \\
\hline $\mathrm{ArN}_{2}{ }_{2}$. & $\begin{array}{l}1500 \mathrm{sccm} \text { Ar-40 sccm N } \\
27 \mathrm{~W}, 5.5 \mathrm{~mm}\end{array}$ & $\begin{array}{c}0 \\
86 \\
83540\end{array}$ & $\begin{array}{c}9 \\
9 \\
2.4\end{array}$ & $\begin{array}{l}9.6 \\
5.6 \\
0.5\end{array}$ & $\begin{array}{c}104 \\
80 \\
40\end{array}$ & $\begin{array}{l}5.6 \\
5.5 \\
6.6\end{array}$ \\
\hline $\mathrm{ArN}_{2} 3$. & $\begin{array}{l}2000 \mathrm{sccm} \text { Ar-40 sccm N } \\
27 \mathrm{~W}, 10.5 \mathrm{~mm}\end{array}$ & $\begin{array}{c}0 \\
81 \\
83529\end{array}$ & $\begin{array}{c}2 \\
2 \\
0.5\end{array}$ & $\begin{array}{l}6.6 \\
5.9 \\
1.6\end{array}$ & $\begin{array}{l}73 \\
79 \\
36\end{array}$ & $\begin{array}{l}5.8 \\
5.4 \\
6.5\end{array}$ \\
\hline $\mathrm{ArN}_{2} 4$. & $\begin{array}{l}2000 \mathrm{sccm} \text { Ar-40 sccm } \mathrm{N}_{2} \\
27 \mathrm{~W}, 10.5 \mathrm{~mm}, 10 \mathrm{~min}\end{array}$ & $\begin{array}{c}0 \\
92 \\
83488\end{array}$ & $\begin{array}{c}4 \\
3 \\
0.5\end{array}$ & $\begin{array}{l}14 \\
6.3 \\
0.5\end{array}$ & $\begin{array}{c}141 \\
101 \\
61\end{array}$ & $\begin{array}{c}5 \\
5.3 \\
5.8\end{array}$ \\
\hline $\mathrm{ArN}_{2}{ }_{5}$. & $\begin{array}{l}2000 \mathrm{sccm} \text { Ar-60 sccm N } \\
27 \mathrm{~W}, 5.5 \mathrm{~mm}\end{array}$ & $\begin{array}{c}0 \\
68 \\
83508\end{array}$ & $\begin{array}{l}17 \\
25 \\
15\end{array}$ & $\begin{array}{l}8.7 \\
2.8 \\
0.5\end{array}$ & $\begin{array}{c}128 \\
68 \\
51\end{array}$ & $\begin{array}{l}5.5 \\
4.8 \\
6.3\end{array}$ \\
\hline $\mathrm{ArN}_{2} 6$. & $\begin{array}{l}2000 \mathrm{sccm} \text { Ar-60 sccm } \mathrm{N}_{2} \\
27 \mathrm{~W}, 8.5 \mathrm{~mm}\end{array}$ & $\begin{array}{c}0 \\
79 \\
83520\end{array}$ & $\begin{array}{c}3 \\
4 \\
0.5\end{array}$ & $\begin{array}{c}4.9 \\
4 \\
0.5\end{array}$ & $\begin{array}{l}62 \\
55 \\
24\end{array}$ & $\begin{array}{l}5.8 \\
5.8 \\
6.6\end{array}$ \\
\hline $\mathrm{ArN}_{2}{ }_{7}$. & $\begin{array}{l}1500 \mathrm{sccm} \text { Ar-60 sccm } \mathrm{N}_{2} \\
27 \mathrm{~W}, 5.5 \mathrm{~mm}\end{array}$ & $\begin{array}{c}0 \\
66 \\
83503\end{array}$ & $\begin{array}{c}3 \\
3 \\
0.5\end{array}$ & $\begin{array}{l}4.5 \\
3.4 \\
0.5\end{array}$ & $\begin{array}{l}59 \\
52 \\
22\end{array}$ & $\begin{array}{c}6 \\
6 \\
6.7\end{array}$ \\
\hline $\mathrm{ArN}_{2}{ }_{8}$. & $\begin{array}{l}2000 \mathrm{sccm} \mathrm{Ar}-100 \mathrm{sccm} \mathrm{N} \\
30 \mathrm{~W}, 5.5 \mathrm{~mm}\end{array}$ & $\begin{array}{c}0 \\
84 \\
83484\end{array}$ & $\begin{array}{c}11 \\
11 \\
5\end{array}$ & $\begin{array}{l}6.5 \\
3.8 \\
0.5\end{array}$ & $\begin{array}{l}73 \\
52 \\
29\end{array}$ & $\begin{array}{l}5.8 \\
5.5 \\
6.4\end{array}$ \\
\hline $\mathrm{ArN}_{2} \mathrm{O}_{2} \_1$. & $\begin{array}{l}2000 \mathrm{sccm} \mathrm{Ar}-40 \mathrm{sccm} \mathrm{N} 2^{-10} \mathrm{sccm} \mathrm{O} \\
25 \mathrm{~W}, 5.5 \mathrm{~mm}\end{array}$ & $\begin{array}{c}0 \\
76 \\
83486\end{array}$ & $\begin{array}{c}20 \\
19 \\
16.6\end{array}$ & $\begin{array}{l}8.8 \\
1.8 \\
0.5\end{array}$ & $\begin{array}{c}104 \\
59 \\
53\end{array}$ & $\begin{array}{l}5.4 \\
5.5 \\
5.8\end{array}$ \\
\hline $\mathrm{ArN}_{2} \mathrm{O}_{2} \_2$. & $\begin{array}{l}2000 \mathrm{sccm} \text { Ar-40 sccm N } 2_{2}-20 \mathrm{sccm} \mathrm{O} \\
25 \mathrm{~W}, 5.5 \mathrm{~mm}\end{array}$ & $\begin{array}{c}0 \\
74 \\
83484\end{array}$ & $\begin{array}{l}37 \\
14 \\
8.5\end{array}$ & $\begin{array}{l}12 \\
2.7 \\
0.5\end{array}$ & $\begin{array}{c}128 \\
64 \\
43\end{array}$ & $\begin{array}{l}5.3 \\
4.9 \\
5.9\end{array}$ \\
\hline $\mathrm{ArO}_{2} 1$. & $\begin{array}{l}2000 \mathrm{sccm} \text { Ar-20 sccm O } \\
25 \mathrm{~W}, 5.5 \mathrm{~mm}\end{array}$ & $\begin{array}{c}0 \\
73 \\
83451\end{array}$ & $\begin{array}{l}80 \\
37 \\
43\end{array}$ & $\begin{array}{l}9.3 \\
0.5 \\
0.5\end{array}$ & $\begin{array}{c}113 \\
50 \\
45\end{array}$ & $\begin{array}{l}5.5 \\
4.9 \\
5.8\end{array}$ \\
\hline $\mathrm{ArO}_{2} 2$. & $\begin{array}{l}2000 \mathrm{sccm} \text { Ar-40 sccm O } \\
27 \mathrm{~W}, 5.5 \mathrm{~mm}\end{array}$ & $\begin{array}{c}0 \\
84 \\
83388\end{array}$ & $\begin{array}{l}75 \\
41 \\
35\end{array}$ & $\begin{array}{c}13 \\
1 \\
0.5\end{array}$ & $\begin{array}{l}122 \\
66 \\
57\end{array}$ & $\begin{array}{c}5 \\
4.4 \\
5.9\end{array}$ \\
\hline
\end{tabular}




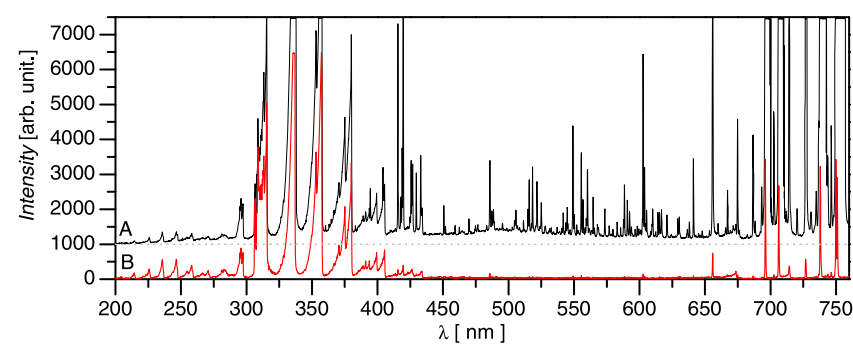

Figure 2. Spectra of plasma plume close to the water surface for different quartz tube-water distances: (A) $d=5.5 \mathrm{~mm}$ and (B) $d=10.5 \mathrm{~mm}$, in the case of the $2000 \mathrm{sccm} \mathrm{Ar}, 25 \mathrm{~W}$ discharge. The spectra are shifted in intensity for clarity.

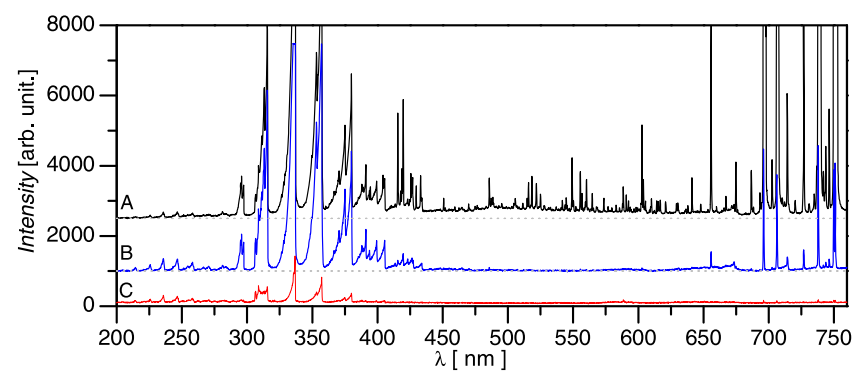

Figure 3. Spectra of plasma plume close to the water surface for (A) $2000 \mathrm{sccm} \mathrm{Ar}-40 \mathrm{sccm} \mathrm{N} 27 \mathrm{~W}$, (B) $2000 \mathrm{sccm} \mathrm{Ar}-60 \mathrm{sccm} \mathrm{N}{ }_{2}$ $27 \mathrm{~W}$ and (C) $2000 \mathrm{sccm} \mathrm{Ar}-100 \mathrm{sccm} \mathrm{N}_{2} 30 \mathrm{~W}$. The spectra are shifted in intensity for clarity.

similar to that of the pure Ar discharge (Ar_1), which is also shown by the obtained similar $\mathrm{H}_{2} \mathrm{O}_{2}$ concentrations (and the measured spectra, not shown here, where the emission intensity of ArI lines were found to be similar as in the case of Ar discharge), while in the case of the $\mathrm{Ar}-\mathrm{O}_{2}$ mixture higher nitrate/nitrite concentrations are obtained, due to the higher creation probability of the $\mathrm{NO}_{2}$ radicals in the gas phase. With the increase of the $\mathrm{O}_{2}$ gas flow rate in the Ar- $\mathrm{O}_{2}$ mixture $\left(\mathrm{ArO}_{2} \_2\right)$ the density of $\mathrm{NO}_{2}$ radicals can be further increased, resulting in higher nitrate and nitrite production in PAW.

The ageing of the PAW at room temperature, already shown by the data presented in table 2, is further illustrated in figure 4 at conditions with very different initial hydrogen peroxide levels in the PAW. The figures indicate that the ageing dynamics depends on the $\mathrm{H}_{2} \mathrm{O}_{2}$ concentration, and in each case the concentrations stabilize after one week.

The most sensitive radical is found to be the $\mathrm{NO}_{2}^{-}$, also due to its low concentration. In the case of initially high $\mathrm{H}_{2} \mathrm{O}_{2}$ concentrations the $\mathrm{NO}_{2}^{-}$radicals recombine within the first hour, while at considerably lower $\mathrm{H}_{2} \mathrm{O}_{2}$ concentrations, figure 4(d) and (f), the recombination of $\mathrm{NO}_{2}^{-}$slows down. At very low initial $\mathrm{H}_{2} \mathrm{O}_{2}$ concentrations the $\mathrm{NO}_{2}^{-}$can survive more than one month. This indicates, that the main recombination pathway for $\mathrm{NO}_{2}^{-}$could be the $\mathrm{NO}_{2}^{-}+\mathrm{H}_{2} \mathrm{O}_{2}+\mathrm{H}^{+}$ $\rightarrow \mathrm{NO}_{3}^{-}+\mathrm{H}_{2} \mathrm{O}+\mathrm{H}^{+}$process. This reaction is found to be effective in acidic conditions $(\mathrm{pH}<6)$ [30], a constant rate being reported for conditions with $\mathrm{pH}$ between 4 and 6 at $25^{\circ} \mathrm{C}$ [31]. In the case of $\mathrm{H}_{2} \mathrm{O}_{2}$ and $\mathrm{NO}_{3}^{-}$radicals we can observe a sharp decrease of concentrations within the first hour, when both initial concentrations are higher than about $60 \mathrm{mg}^{-1}$, figures 4(a) and (b). At lower initial $\mathrm{H}_{2} \mathrm{O}_{2}$ concentrations $\left(10-40 \mathrm{mg}^{-1}\right)$, figures $4(\mathrm{c})$ and (d), the recombination rates for both radicals become smaller, more pronouncedly in the case of $\mathrm{H}_{2} \mathrm{O}_{2}$. Furthermore, when the initial $\mathrm{H}_{2} \mathrm{O}_{2}$ concentration is lower than $5 \mathrm{mg} \mathrm{l}^{-1}$ the $\mathrm{H}_{2} \mathrm{O}_{2}$ radicals disappear totally within one week.

Another important characteristics of PAW is the $\mathrm{pH}$, which is also shown in table 2, as well as its post-discharge evolution. Comparing the different PAWs at $t=0 \mathrm{~min}$, as expected based on the reactions (1)-(4), the $\mathrm{pH}$ correlates with the nitrite/nitrate concentrations, namely, at higher nitrate concentration lower $\mathrm{pH}$ is obtained. However, during the first hour of ageing, when a sharp decrease of concentrations occurs, the $\mathrm{pH}$ also decreases, except for the conditions where the $\mathrm{H}_{2} \mathrm{O}_{2}$ concentration is initially very low e.g. $\mathrm{ArN}_{2} \_4$ and $\mathrm{ArN}_{2}{ }_{6} 6$ conditions. This suggests the influence of the first phase $\mathrm{H}_{2} \mathrm{O}_{2}$ recombination on the $\mathrm{pH}$, i.e. on the $\mathrm{H}^{+}$ion concentration. In order to understand the complex dynamics of the system, a detailed investigation of the processes is needed, which will be the focus of a next work.

Figure 5 (a) and (b) summarizes the different PAW compositions obtained with the treatments listed in table 2 right after the treatment and after one hour of storage, respectively. As already shown in figure 4, during the first hour both the nitrate and hydrogen peroxide concentrations decrease, resulting in a considerable change of the PAW's composition. Figure 5 illustrates the possible PAWs to be obtained with a surface-wave microwave discharge. We note, that with doubling the treatment time, the doubling of the concentrations has been achieved ( $\mathrm{ArN}_{2} \_3$ versus $\left.\mathrm{ArN}_{2} \_4\right)$. Comparing to the condition with the largest $\mathrm{H}_{2} \mathrm{O}_{2}$ in figure 5(a) $\left(84 \mathrm{mg} \mathrm{l}^{-1} \mathrm{H}_{2} \mathrm{O}_{2}\right.$ and $\left.92 \mathrm{mg} \mathrm{l}^{-1} \mathrm{NO}_{3}^{-}\right)$, higher $\mathrm{H}_{2} \mathrm{O}_{2}$ concentration and corresponding lower $\mathrm{NO}_{3}^{-}$concentration can be achieved by further decreasing the treatment distance or increasing the input power in the case of the Ar discharge. For the given condition, the corresponding $\mathrm{NO}_{3}^{-}$ concentration can be further decreased by increasing the Ar gas flow rate, which results in lower air inflow into the plasma plume from the surroundings. On the other extreme, at very low $\mathrm{H}_{2} \mathrm{O}_{2}$ concentrations, the treatments occur close to the afterglow conditions. By further increasing the treatment distance (or decreasing the input power), only neutral species would interact with the water surface, which results in $\mathrm{H}_{2} \mathrm{O}_{2}$ free PAWs. The nitrite-hydrogen peroxide concentration map, figure 5(b), shows the limit for the $\mathrm{H}_{2} \mathrm{O}_{2}$ content of PAW where $\mathrm{NO}_{2}^{-}$radicals can survive longer than one hour, namely in the case of $\mathrm{H}_{2} \mathrm{O}_{2}$ concentrations below $30 \mathrm{mg}^{-1}$.

Finally, figure 6 shows the ratio of the nitrate to hydrogen peroxide concentration as a function of ageing for the different treatment conditions as listed in table 2. By changing the treatment distance and the initial gas mixture composition of the discharge, the $\left[\mathrm{NO}_{3}^{-}\right] /\left[\mathrm{H}_{2} \mathrm{O}_{2}\right]$ concentration ratio can be varied over three orders of magnitude from about 0.5 to 150 (we note that the lowest detection limit of $\mathrm{H}_{2} \mathrm{O}_{2}$ is $0.5 \mathrm{mg} \mathrm{l}^{-1}$, thus in the ratio calculations the concentrations that are lower than that value are taken as 0.5 ). In the case of 

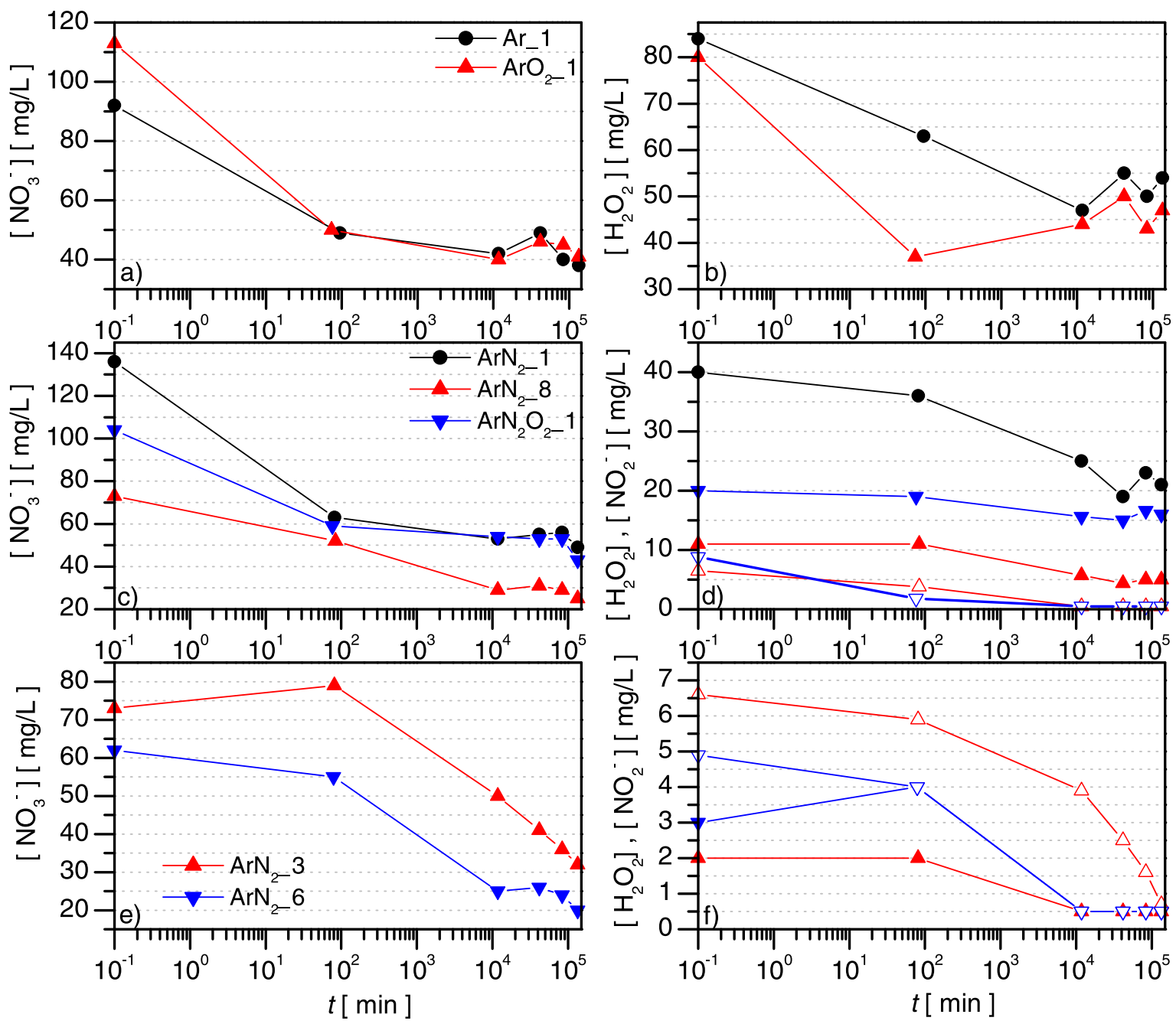

Figure 4. Evolution of radical concentration during PAW storage at room temperature for different treatment conditions. In the right column for the same conditions the closed symbols represent the concentration of $\mathrm{H}_{2} \mathrm{O}_{2}$, while the open symbols that of $\mathrm{NO}_{2}^{-}$.

the treatment conditions where initially $(t=10 \mathrm{~s})$ low $\mathrm{H}_{2} \mathrm{O}_{2}$ concentrations are obtained, the ageing has a more pronounced effect on the concentrations ratio, due to the strong recombination of $\mathrm{H}_{2} \mathrm{O}_{2}$, while the $\mathrm{NO}_{3}^{-}$recombination is much slower (see figures 4(e)-(f)).

\subsection{The PAW produced with the $\mathrm{KHz}$ plasma jet}

Comparing to the surface-wave microwave discharge, the $\mathrm{kHz}$ plasma jet can be more easily ignited in molecular gases, such as nitrogen and oxygen, and consequently in air. For large scale applications, from the economical point of view, this system could have the advantage of using air or air like mixtures instead of more costly rare gases. Figure 7 shows the optical emission spectra of a nitrogen and an $\operatorname{argon~} \mathrm{kHz}$ plasma jet. In both cases the nitrogen band exhibit similar intensities, while in argon discharge a strong $\mathrm{OH}$ band $(309 \mathrm{~nm})$ emission also appears. This could be related to the difference in the electron density, which has also been reflected by the $\mathrm{H}_{2} \mathrm{O}_{2}$ concentrations obtained in PAW, namely higher concentration in the $\mathrm{Ar}$ discharge treated water. The emission intensity of the $\mathrm{NO} \gamma$ bands are also stronger in the argon discharge, however, due to the strong quenching of the excited $\mathrm{NO}$ molecules by $\mathrm{N}_{2}$, this emission can indicate well the presence of NO molecules. In the present work the possibilities given by the nitrogen jet are investigated in detail.

First of all, the evolution of the PAW composition with the treatment time in different treated volumes is investigated. Figure 8 shows the concentrations of the nitrate, nitrite, hydrogen peroxide, as well as the $\mathrm{pH}$ as a function of treatment time in the case of 25,125 and $200 \mathrm{ml}$ treated water. The concentrations have been measured at every six minutes during the treatment. It is found that during the treatment the $\mathrm{H}_{2} \mathrm{O}_{2}$ concentration increases linearly independently of the treated volume. On the other hand, the and $\mathrm{NO}_{3}^{-}$and $\mathrm{NO}_{2}^{-}$ concentrations show a saturation at the lower $25 \mathrm{ml}$ treated volume, which can be related to the recombination processes involving $\mathrm{H}_{2} \mathrm{O}_{2}$, that is produced here in higher concentration. This effect does not appear at the higher treated volumes, thanks to the lower $\mathrm{H}_{2} \mathrm{O}_{2}$ concentrations obtained during the same treatment time. The $\mathrm{pH}$ is found to decrease linearly with the treatment time, which is related to the increase of the nitrite and nitrate concentrations. The error bars shown in 


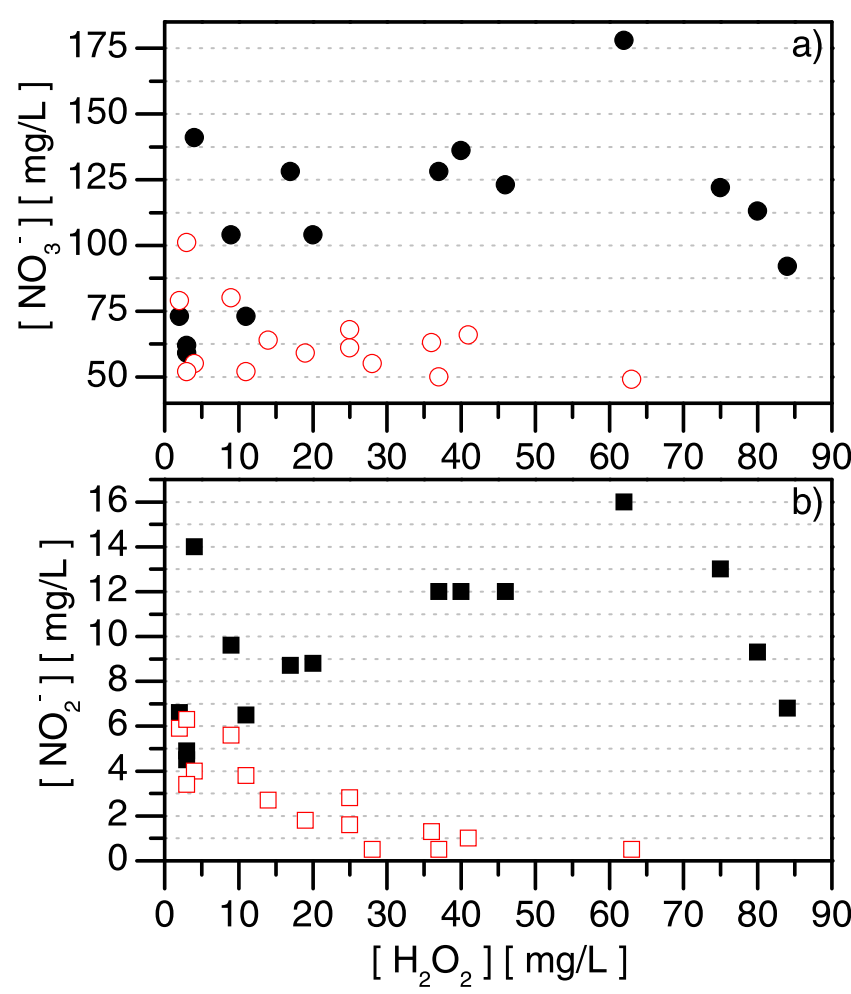

Figure 5. The nitrate-hydrogen peroxide (a) and nitrite-hydrogen peroxide concentration (b) maps right after the plasma treatment (closed symbols) and one hour storage (open symbols). The data correspond to all the conditions listed in table 2 .

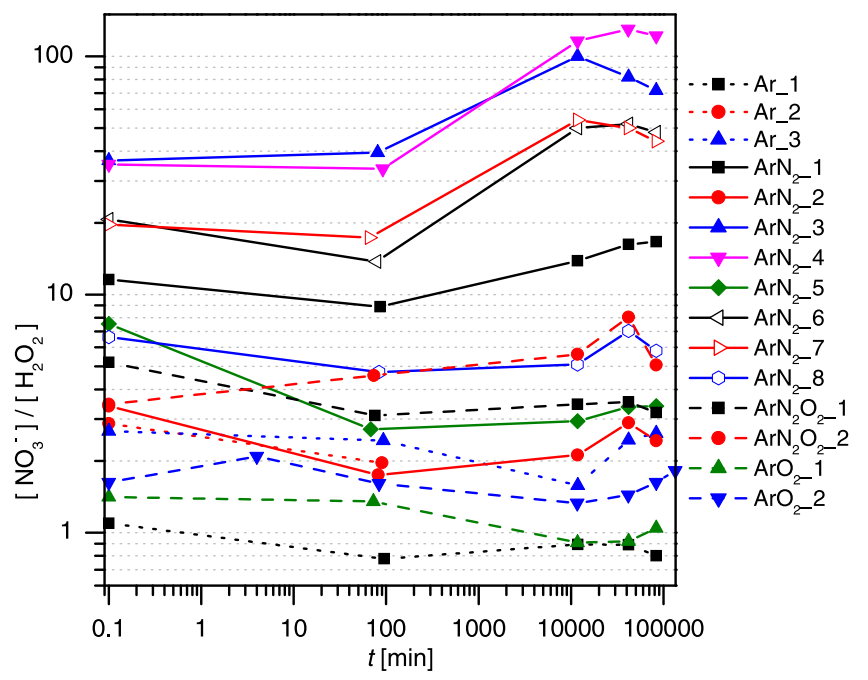

Figure 6. The ratio of the nitrate to peroxide concentration as a function of ageing time for the different treatment conditions as listed in table 2 .

figure are obtained by averaging four independent sample treatments. The treatment of the smallest volume is the most sensitive case, the errors are due to the adjustment of the capillary orifice-water surface distance, which can slightly change also during treatment due to the water evaporation.

Figure 9 shows the evolution of the concentrations and $\mathrm{pH}$ during the storage at room temperature of PAWs produced in different volumes. Similarly to the PAW produced by the surface-wave microwave discharge, the post-discharge

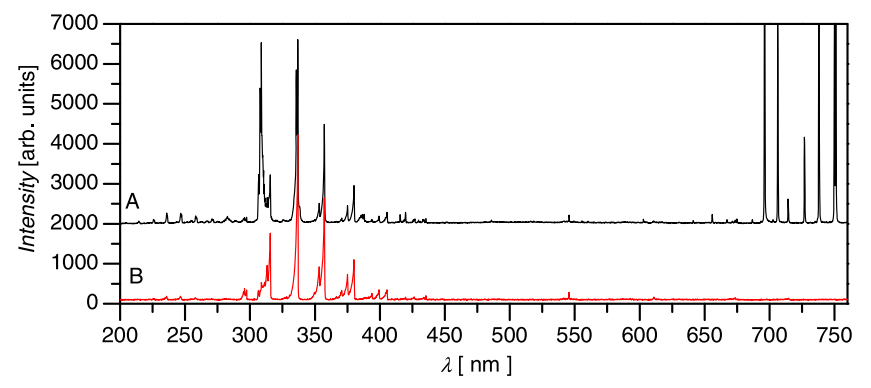

Figure 7. The optical emission spectra of the argon (A) and nitrogen (B) $\mathrm{kHz}$ plasma jets recorder from the region right below the capillary exit.

evolution of radicals in PAW strongly depends on the absolute concentrations. Accordingly, the sharpest first phase decrease can be observed in the smallest $25 \mathrm{ml}$ volume PAW, where the highest concentrations have been obtained. Especially, the $\mathrm{NO}_{2}^{-}$concentration drops fast, due to the recombination of $\mathrm{NO}_{2}^{-}$with $\mathrm{H}_{2} \mathrm{O}_{2}$. In the larger, less concentrated volume, with the lowest initial $\mathrm{H}_{2} \mathrm{O}_{2}$ concentration, the nitrite and nitrate recombination is more moderate, with the $\mathrm{NO}_{2}^{-}$ being preserved for months.

In the case of the nitrogen $\mathrm{kHz}$ plasma jet one controlling parameter can be the treatment distance. Figure 10 shows the concentrations obtained by treating the $25 \mathrm{ml}$ volume at different capillary orifice to the water surface distances. As expected, with the decrease of the distance, due to the increase of the electron density the formation of $\mathrm{H}_{2} \mathrm{O}_{2}$ radicals is strongly enhanced, while the nitrate and nitrite concentrations change just slightly. Accordingly, with this method the $\left[\mathrm{NO}_{3}^{-}\right] /\left[\mathrm{H}_{2} \mathrm{O}_{2}\right]$ concentration ratio could be varied in the 2-12 range. However the ageing tends to equalize this ratio.

\subsection{Controlling the ageing of PAW}

As we have seen, the most affected radical by storage is the $\mathrm{NO}_{2}^{-}$, and its evolution strongly depends on the $\mathrm{H}_{2} \mathrm{O}_{2}$ concentration. In order to preserve the $\mathrm{NO}_{2}^{-}$, the concentration of $\mathrm{H}_{2} \mathrm{O}_{2}$ and its recombination should be controlled. One possibility is to rely on a Fenton type reaction, which controls the $\mathrm{H}_{2} \mathrm{O}_{2}$ recombination. This reaction is believed to have more pathways: (i) the Fenton $\mathrm{M}^{2+}+\mathrm{H}_{2} \mathrm{O}_{2} \rightarrow \mathrm{M}^{3+}+\mathrm{OH}+\mathrm{OH}^{-}$or (ii) the catalase $\mathrm{M}^{2+}+\mathrm{H}_{2} \mathrm{O}_{2} \rightarrow \mathrm{MO}^{2+}+\mathrm{H}_{2} \mathrm{O}, \mathrm{MO}^{2+}+\mathrm{H}_{2} \mathrm{O}_{2} \rightarrow$ $\mathrm{M}^{2+}+\mathrm{H}_{2} \mathrm{O}+\mathrm{O}_{2}$. In our study we use copper as a metal.

In order to test this effect, we compared the evolution of two different samples produced under same treatment conditions: (i) plasma-activated water (PAW) and (ii) plasmaactivated water with a copper plate inserted during the treatment $(\mathrm{PAW}+\mathrm{Cu})$. The applied copper plate is $1 \mathrm{~mm}$ thick of $70 \times 10 \mathrm{~mm}^{2}$ size. Figure 11 shows the ageing of the samples activated with the surface-wave microwave discharge. The results illustrate, that copper contributes to the increase of the $\mathrm{H}_{2} \mathrm{O}_{2}$ recombination, while it slows down that of the $\mathrm{NO}_{2}^{-}$. In this way $\mathrm{NO}_{2}^{-}$can be preserved longer (We note that the effect depends on the concentration of $\mathrm{H}_{2} \mathrm{O}_{2}$.). This indicates that the copper mediated $\mathrm{H}_{2} \mathrm{O}_{2}$ recombination changes the system's chemical kinetics. In order to be able to control the ageing of PAW, a deeper understanding of the 


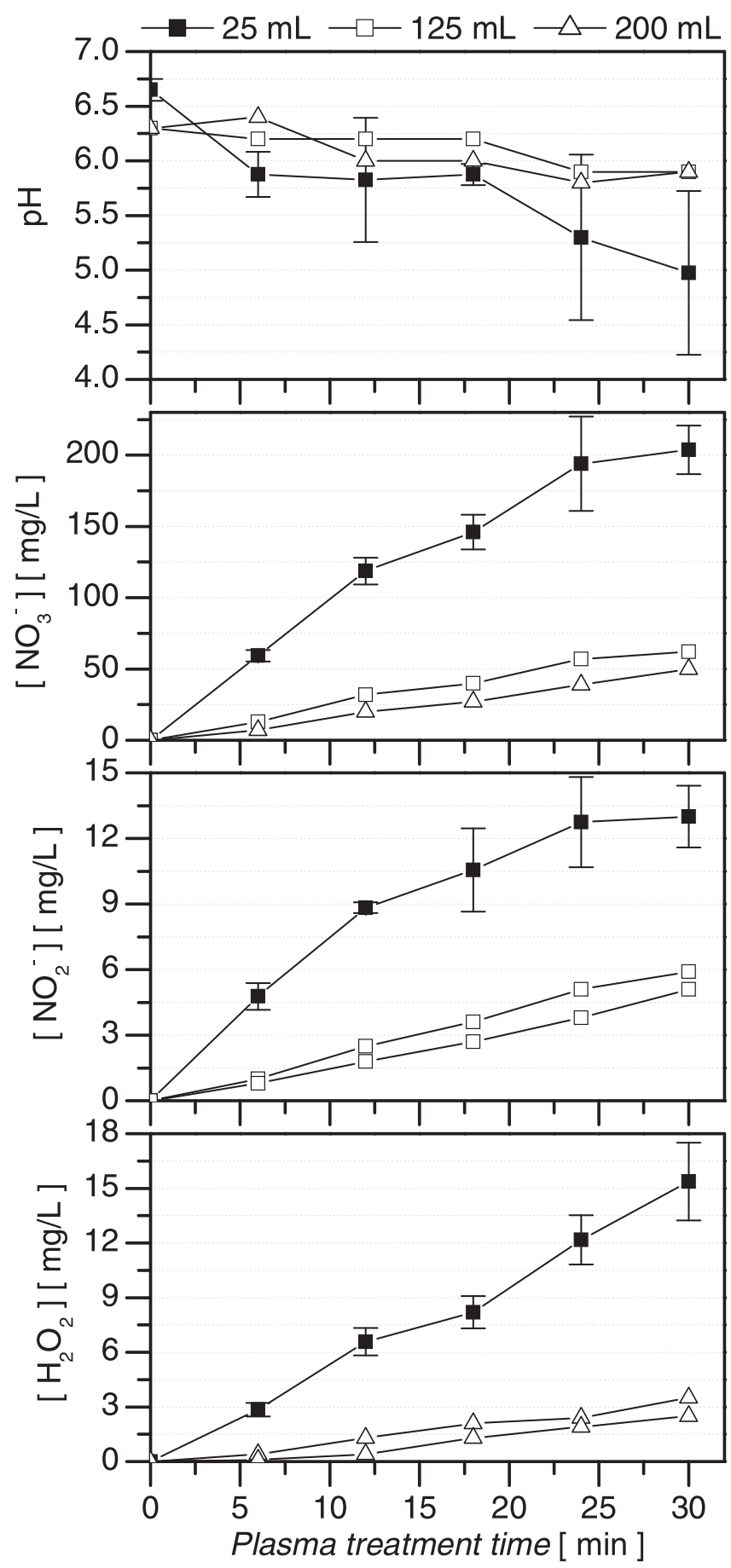

Figure 8. The evolution of the concentrations and the $\mathrm{pH}$ during 30 min treatment with the nitrogen atmospheric pressure plasma jet in the case of different treated volumes. The discharge is sustained with $12 \mathrm{kV}$ and $28 \mathrm{kHz}$ sinusoidal waveform, and the capillarywater surface distance is $10 \mathrm{~mm}$.

chemical pathways is required, which can be the focus of a future work.

\section{Summary}

An atmospheric pressure surface-wave microwave discharge and a $\mathrm{kHz}$ plasma jet have been used to activate purified water
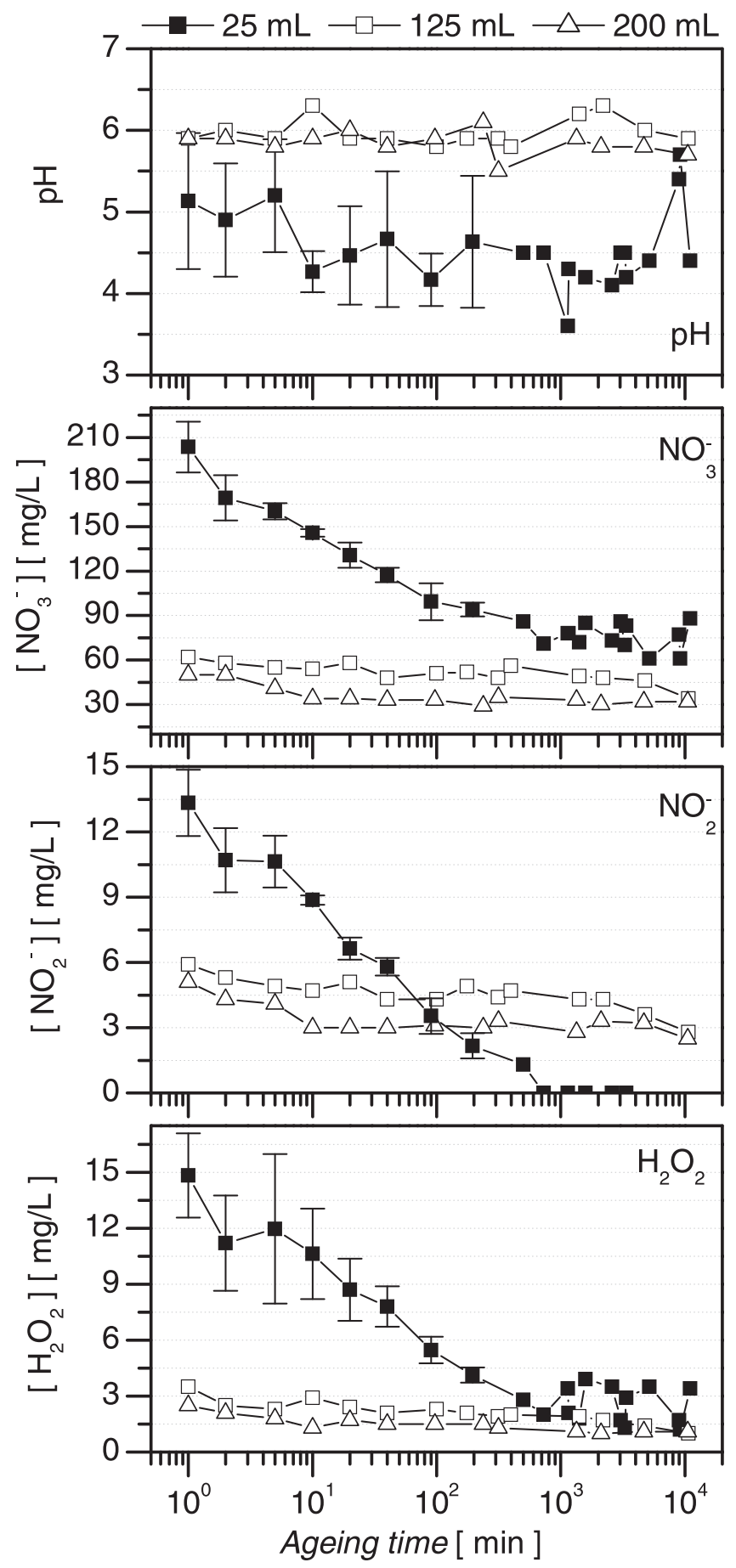

Figure 9. Ageing at room temperature of PAWs obtained by $30 \mathrm{~min}$ nitrogen plasma jet treatment.

(W) and to study the possibility to tune the composition of plasma activated water (PAW) with the discharge and treatment conditions.

The surface-wave microwave discharge has been ignited in $\mathrm{Ar}$ and in $\mathrm{Ar} / \mathrm{N}_{2} / \mathrm{O}_{2}$ binary and ternary mixtures with powers in the $25-30 \mathrm{~W}$ range. The different gas mixture conditions allows to tune the electron and species densities at the plasma-water interaction point. The treatments have been conducted by putting $32 \mathrm{ml} \mathrm{W}$ in contact with the plasma plume, with the water surface being at $5.5,8.5$ and $10.5 \mathrm{~mm}$ 

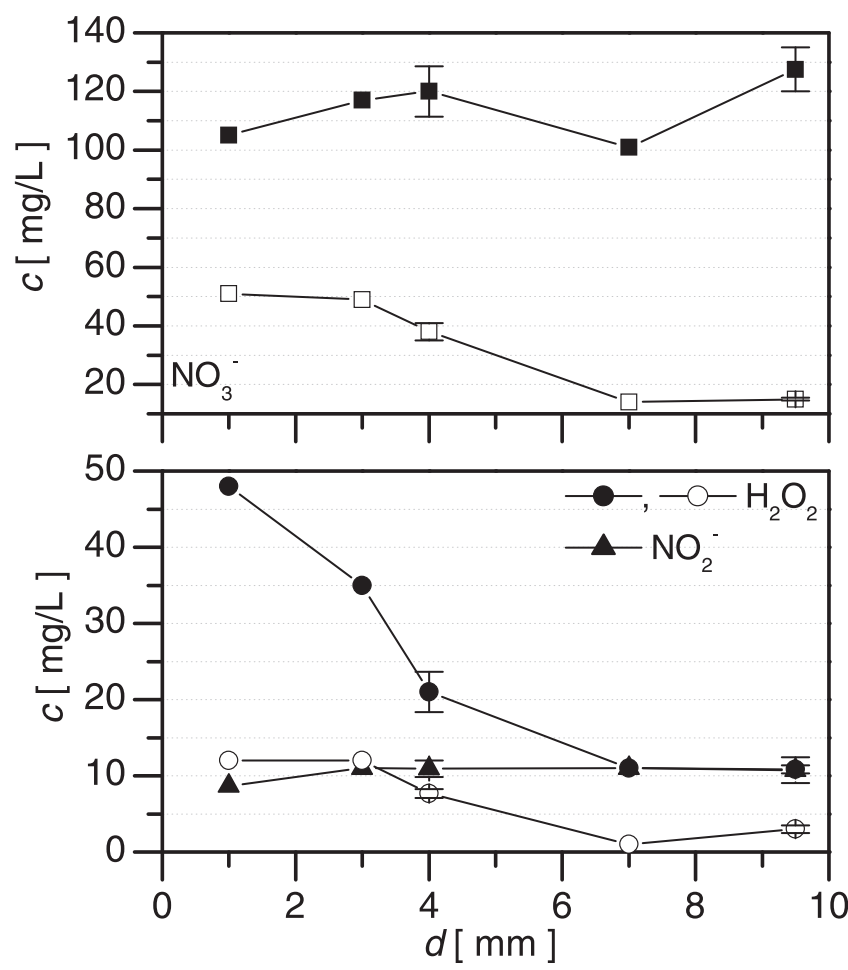

Figure 10. Concentrations as a function of treatment distance within the first minute after treatment (full symbols) and after $50000 \mathrm{~min}$ $(35 \mathrm{~d})$ storage (open symbols) in the case of $25 \mathrm{ml} 10$ min plasma jet treatment.

distances from the edge of the discharge quartz tube. It is shown, that by varying the initial gas mixture composition and treatment distance, the absolute radical concentrations in the plasma activated water (PAW) can be varied in the range of $0.5-85 \mathrm{mg} \mathrm{l}^{-1}$ for $\mathrm{H}_{2} \mathrm{O}_{2}, 20-180 \mathrm{mg} \mathrm{l}^{-1}$ for $\mathrm{NO}_{3}^{-}$and $0.5-14 \mathrm{mg} \mathrm{l}^{-1}$ for $\mathrm{NO}_{2}^{-}$. The ageing of PAW is found to depend on the absolute concentration of radicals, and most specifically on the concentration of $\mathrm{H}_{2} \mathrm{O}_{2}$, which governs first of all the recombination of $\mathrm{NO}_{2}^{-}$. When the initial concentrations of $\mathrm{H}_{2} \mathrm{O}_{2}$ and $\mathrm{NO}_{3}^{-}$are higher than about $60 \mathrm{mg} \mathrm{l}^{-1}$, a sharp decrease of both concentrations occurs within the first hour, while the $\mathrm{NO}_{2}^{-}$radicals recombine totally. At lower initial $\mathrm{H}_{2} \mathrm{O}_{2}$ concentrations (10-40 $\mathrm{mg} \mathrm{l}^{-1}$ ), the recombination rates for both $\mathrm{H}_{2} \mathrm{O}_{2}$ and $\mathrm{NO}_{3}^{-}$become smaller, more pronouncedly in the case of $\mathrm{H}_{2} \mathrm{O}_{2}$. Finally, when the initial $\mathrm{H}_{2} \mathrm{O}_{2}$ concentration is lower than $5 \mathrm{mg} \mathrm{l}^{-1}$ the $\mathrm{H}_{2} \mathrm{O}_{2}$ radicals disappear totally within one week, while the $\mathrm{NO}_{2}^{-}$can survive more than one month. It is further found, that the concentration ratio of $\mathrm{NO}_{3}^{-}$and $\mathrm{H}_{2} \mathrm{O}_{2}$ radicals is varied over three orders of magnitude, which is preserved during months of storage at room temperature. The $\mathrm{pH}$ of PAWs right after the treatment have values between 5 and 6 , and a correlation is found between the $\mathrm{pH}$ and the nitrite/ nitrate concentrations, namely, at higher nitrate concentration lower $\mathrm{pH}$ is obtained. During the first hour of ageing, in the PAWs where a sharp decrease of the concentrations occurred -which exclude conditions where the $\mathrm{H}_{2} \mathrm{O}_{2}$ concentration is initially very low-, the $\mathrm{pH}$ decreased to values between 4.4 and 5.5. However, at the latter stage of ageing, with the

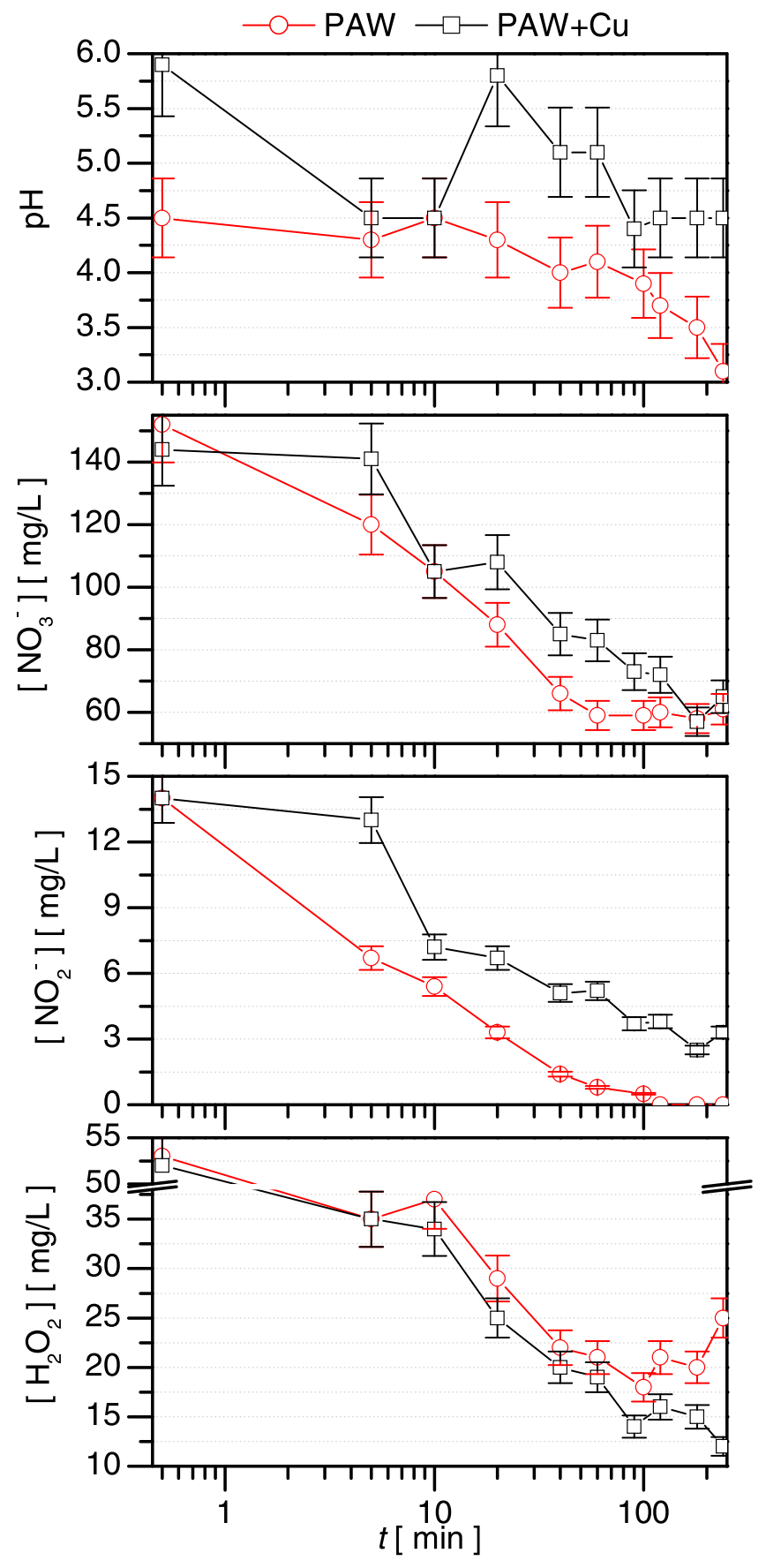

Figure 11. Ageing of microwave produced PAWs: plasma-activated water (PAW) and plasma-activated water with a copper plate inserted during the treatment $(\mathrm{PAW}+\mathrm{Cu})$.

stabilization of the concentrations the $\mathrm{pH}$ increased again to values between 5.8 and 6.7. A correlation is found between the $\mathrm{pH}$ variation and the $\mathrm{H}_{2} \mathrm{O}_{2}$ recombination.

The kHz plasma jet has been ignited in $\mathrm{N}_{2}$ gas with a sinusoidal voltage waveform of $28 \mathrm{kHz}$ and maximum voltage of $12 \mathrm{kV}$. With this source the effect of the treatment distance and treated volume on the PAW composition has been studied. It is shown, that by varying the distance in the $1-10 \mathrm{~mm}$ range, the $\left[\mathrm{NO}_{3}^{-}\right] /\left[\mathrm{H}_{2} \mathrm{O}_{2}\right]$ concentration ratio can be tuned within one order of magnitude, which is partially preserved during ageing. At the same time, the absolute concentrations in the $25 \mathrm{ml}$ 
PAW vary in the $0.5-50 \mathrm{mg} \mathrm{l}^{-1}$ for $\mathrm{H}_{2} \mathrm{O}_{2}, 15-130 \mathrm{mg} \mathrm{l}^{-1}$ for $\mathrm{NO}_{3}^{-}$and $0.5-10 \mathrm{mg} \mathrm{l}^{-1}$ for $\mathrm{NO}_{2}^{-}$. With the increase of the treated volume up to $200 \mathrm{ml}$, lower radical concentrations are achieved, with the $\mathrm{H}_{2} \mathrm{O}_{2}$ reaching as low as $4 \mathrm{mgl}^{-1}$, which results in the fast recombination of $\mathrm{H}_{2} \mathrm{O}_{2}$ and the preservation of $\mathrm{NO}_{2}^{-}$for months.

In order to control the $\mathrm{H}_{2} \mathrm{O}_{2}$ concentration and thus the $\mathrm{NO}_{2}^{-}$radicals recombination, the application of a Fenton type reaction is suggested, where the $\mathrm{H}_{2} \mathrm{O}_{2}$ recombination is mediated by metal ions. By inserting a copper surface into PAW during or after plasma treatment, it is demonstrated that the recombination pathway of $\mathrm{H}_{2} \mathrm{O}_{2}$ can be altered, and the $\mathrm{NO}_{2}^{-}$radicals can be preserved longer.

\section{Acknowledgments}

The work has been supported by the Hungarian Science Foundation NKFIH, through project K-115805, by the Croatian Science Foundation, through project IP-2013-112753 and by the Croatian-Hungarian bilateral project TéT_16-1-2016-0014.

\section{ORCID iDs}

Kinga Kutasi (ib https://orcid.org/0000-0001-6082-1853 Dean Popović (iD https://orcid.org/0000-0003-3906-3482 Nikša Krstulović (iD https://orcid.org/0000-0001-6443-2417 Slobodan Milošević (10 https://orcid.org/0000-00024455-7869

\section{References}

[1] Kamgang-Youbi G, Herry J-M, Bellon-Fontaine M-N Brisset J-L, Doubla A and Naitali M 2007 Appl. Environ. Microbiol. 734791

[2] Kamgang-Youbi G, Herry J-M, Brisset J-L, Bellon-Fontaine M-N, Doubla A and Naïtali M 2008 Appl. Microbiol. Biotechnol. 81449

[3] Naïtali M, Kamgang-Youbi G, Herry J-M, Bellon-Fontaine M-N and Brisset J-L 2010 Appl. Environ. Microbiol. 767662

[4] Ikawa S, Kitano K and Hamaguchi S 2010 Plasma Process. Polym. 733

[5] Traylor M J, Pavlovich M J, Karim S, Hait P, Sakiyama Y, Clark D S and Graves D B 2011 J. Phys. D: Appl. Phys. 44 472001

[6] Oehmigen K, Hähnel M, Brandenburg R, Wilke C, Weltmann K-D and von Woedtke T 2010 Plasma Process. Polym. 7250

[7] Oehmigen K, Winter J, Hähnel M, Wilke C, Brandenburg R, Weltmann K-D and von Woedtke T 2011 Plasma Process. Polym. 8904

[8] Kobayashi T, Iwata N, Oh J-S, Hashizume H, Ohta T, Takeda K, Ishikawa K, Hori M and Ito M 2017 J. Phys. D: Appl. Phys. $\mathbf{5 0} 155208$
[9] Tasaki T, Ohshima T, Usui E, Ikawa S, Kitano K, Maeda N and Momoi Y 2017 Dent. Mater. J. 36422

[10] Tanaka H, Mizuno M, Ishikawa K, Nakamura K, Kajiyama H, Kano H, Kikkawa F and Hori M 2011 Plasma Med. 1265

[11] Utsumi F, Kajiyama H, Nakamura K, Tanaka H, Mizuno M, Ishikawa $\mathrm{K}$, Kondo $\mathrm{H}$, Kano $\mathrm{H}$, Hori $\mathrm{M}$ and Kikkawa $\mathrm{F}$ 2013 PLoS One 8 e81576

[12] Takai E, Ohashi G, Yoshida T, Särgjerd K M, Zako T, Maeda M, Kitano K and Shiraki K 2014 Appl. Phys. Lett. 104023701

[13] Puač N, Gherardi M and Shiratani M 2017 Plasma Process. Polym. 151700174

[14] Sivachandiran L and Khacef A 2017 RSC Adv. 71822

[15] Thirumdas R, Kothakota A, Annapure U, Siliveru K, Blundell R, Gatt R and Valdramidis V P 2018 Trends Food Sci. Technol. $7721 ? 31$

[16] Jukák J, Scholtz V, Kotúčová S and Janoušková O 2012 Phys. Med. 28230

[17] Brisset J-L and Pawlat J 2016 Plasma Chem. Plasma Process. 36355

[18] Laurita R, Barbieri D, Gherardi M, Colombo V and Lukes P 2015 Clin. Plasma Med. 353

[19] Shen J, Tian Y, Li Y, Ma R, Zhang Q, Zhang J and Fang J 2016 Sci. Rep. 628505

[20] Julák J, Hujacová A, Scholtz V, Khun J and Holada K 2018 Plasma Phys. Rep. 44125

[21] Lukes P, Dolezalova E, Sisrova I and Clupek M 2014 Plasma Sources Sci. Technol. 23015019

[22] Ito T, Uchida G, Nakajima A, Takenaka K and Setsuhara Y 2017 Japan. J. Appl. Phys. 56 01AC06

[23] Wang B, Liu D, Zhang Z, Li Q, Liu Z, Guo L, Wang X and Kong M G 2017 J. Phys. D: Appl. Phys. 50305202

[24] Zaplotnik R, Kregar Z, Bišćan M, Vesel A, Cvelbar U, Mozetič M and Milošević S 2014 Eur. Phys. Lett. 10625001

[25] Machala Z, Tarabova B, Hensel K, Spetlikova E, Sikurova L and Lukes P 2013 Plasma Process. Polym. 10649

[26] Krcma F, Tsonev I, Smejkalová K, Truchlá D, Kozáková Z, Zhekova M, Marinova P, Bogdanov T and Benova E 2018 J. Phys. D: Appl. Phys. $\mathbf{5 1} 414001$

[27] Kutasi K, Noel C, Belmonte T and Guerra V 2016 Plasma Sources Sci. Technol. 25055014

[28] Moisan M and Zakrzewski Z 1991 J. Phys. D: Appl. Phys. 241025

[29] Kutasi K, Sá P and Guerra V 2012 J. Phys. D: Appl. Phys. 45 195205

[30] Brisset J-L and Hnatiuc E 2012 Plasma Chem. Plasma Process. 32655

[31] Lobachev V L and Rudakov E S 2006 Russ. Chem. Rev. 75375

[32] Liu F et al 2010 Plasma Process. Polym. 7231

[33] Pavlovich M J, Chang H-W, Sakiyama Y, Clark D S and Grave D B 2013 J. Phys. D: Appl. Phys. 46145202

[34] Ercan U K, Wang H, Ji H, Fridman G, Brooks A D and Joshi S G 2013 Plasma Process. Polym. 10544

[35] van Gils C A J, Hofmann S, Boekema B K H L, Brandenburg R and Bruggeman P J 2013 J. Phys. D: Appl. Phys. 46175203

[36] Girard F, Badets V, Blanc S, Gazeli K, Marlin L, Authier L, Svarnas P, Sojic N, Clément F and Arbault S 2016 RSC Adv. 678457

[37] Vlad I-E and Anghel S D 2017 J. Electrostat. 87284

[38] Chen Z, Liu D, Chen C, Xu D, Liu Z, Xia W, Rong M and Kong M G 2018 J. Phys. D: Appl. Phys. 51325201

[39] Oh J-S, Szili J E, Ogawa K, Short R D, Ito M, Furuta H and Hatta A 2018 Japan. J. Appl. Phys. 57 0102B9 